\title{
Sistem Pendukung Keputusan Pembelian Mobil dengan Membandingkan Metode Analytic Hierachy Process dan Fuzzy Associative Memory
}

\author{
Annisya Agustina Awalinah1, ${ }^{*}$, Satria Perdana Arifin², Maksum Ro' is Adin Saf3 \\ 1 Program Studi Teknik Informatika, Politeknik Caltex Riau, \\ (corresponding author) agustina13ti@mahasiswa.pcr.ac.id*, satria@pcr.ac.id, maksum@pcr.ac.id
}

\begin{abstract}
Along with the growth of automotive in Indonesia increasing, car industries compete each other to produce and market new cars which have variant specification. It makes customers feel difficult to decide buying suitable car based on their criteria and needs. Therefore, in this research will be developed Decision Support System for buying car to ease cutomers determining which car to buy. The Decision Support System use Analytic Hierarchy Process (AHP) and Fuzzy Associative Memory (FAM) method for comperative analyse. This reserach use two testing methods that is Black Box Testing using UAT and user testing using quesioner. The results of Black Box Testing is the system successfully built $100 \%$ and run according to expectation. The result of user testing is the recommendation for buying car using FAM is more suitable in user expectation than the recommendation using AHP. Moreover, in terms of usability quality prospective car buyers felt that system using FAM method is $80 \%$ usefulness, $100 \%$ ease of use, $100 \%$ ease of learning and $100 \%$ satisfaction than system using AHP method.
\end{abstract}

Keyword- decision support system, car, ahp, fam

Seiring dengan perkembangan dunia otomotif di Indonesia yang semakin meningkat, perusahaan pabrikan mobil saling bersaing untuk memproduksi dan memasarkan mobil-mobil baru dengan spesifikasi yang semakin beragam. Hal ini membuat para calon pembeli mobil kesulitan untuk menentukan sendiri mobil mana yang sesuai dengan kriteria dan kebutuhannya. Berdasarkan permasalahan tersebut maka dibangunlah sebuah sistem pendukung keputusan untuk pembelian mobil guna mempermudah para calon pembeli mobil untuk menentukan mobil mana yang akan dibeli. Sistem ini dibangun dengan membandingkan metode Analytic Hierarchy Process (AHP) dengan metode Fuzzy Associative Memory (FAM). Kemudian, dilakukan dua buah pengujian terhadap sistem yaitu pengujian blackbox menggunakan UAT yang menghasilkan bahwa sistem $100 \%$ berhasil dibangun dan berjalan sesuai dengan yang diinginkan, dan pengujian terhadap responden dengan menggunakan kuesioner yang menghasilkan bahwa hasil rekomendasi mobil oleh metode FAM lebih sesuai dengan harapan pengguna dibanding hasil dari metode AHP. Selain itu, dari segi kualitas usability calon pembeli mobil menyatakan bahwa sistem dengan menggunakan metode FAM 80 \% lebih berguna, 100\% lebih mudah digunakan, $100 \%$ lebih mudah dipelajari, serta 100\% lebih menarik dibandingkan sistem dengan menggunakan metode AHP.

Kata Kunci-sistem pendukung keputusan, mobil, ahp, fam

\section{Pendahuluan}

A. Latar Belakang

Perkembangan industri otomotif di Indonesia saat ini semakin berkembang. Hal ini dapat dilihat dari jumlah produksi, jumlah penjualan, hingga jumlah mobil yang beredar di Indonesia semakin meningkat. Berdasarkan laporan yang dirilis oleh Gabungan Industri Kendaraan Bermotor (Gaikindo), pada bulan November 2016 perusahaan pabrikan mobil di Indonesia telah memproduksi mobil sebanyak 107.719 unit, angka ini meningkat dari bulan sebelumnya yang hanya 104.130 unit [1]. Sehingga dapat disimpulkan bahwa terjadi peningkatan produksi mobil yang cukup tinggi di Indonesia hanya dalam kurun waktu satu bulan. Berdasarkan survey yang digelar oleh Google dan Netpop alasan terbesar seseorang membeli mobil adalah untuk mengakomodasi jumlah keluarga yang bertambah besar [2]. Di Indonesia sendiri terdapat banyak merek mobil yang beredar di pasaran, berdasarkan laporan Gaikindo, tiga merek mobil terlaris di Indonesia adalah merek Toyota, Honda dan Daihatsu.

Seiring dengan berkembangnya zaman dan teknologi, semakin banyak mobil dengan inovasi terbaru dan spesifikasi yang beragam yang dikeluarkan oleh perusahan pabrikan mobil. Banyaknya mobil dengan jenis dan spesifikasi yang beragam yang dihadapkan kepada calon pembeli mobil menyebabkan semakin sulitnya calon pembeli mobil untuk menentukan sendiri mobil mana yang akan dibelinya. Hasil survey yang dilakukan oleh Google dan Netpop menyatakan bahwa seseorang memerlukan waktu sekitar 2.9 bulan untuk menentukan mobil mana yang akan dibeli. Dari seluruh responden hanya 28 persen saja orang yang tahu persis mobil mana yang mereka inginkan dan selebihnya masih belum dapat memutuskan mobil mana yang akan dibelinya. Oleh karena itu masyarakat membutuhkan sebuah media sebagai 
alat bantu yang dapat mempermudah dan mempercepat dalam pemilihan mobil yang sesuai dengan nilai kriteria dan kebutuhannya.

Berdasarkan permasalahan tersebut dibangunlah sebuah sistem pendukung keputusan untuk pembelian mobil untuk mempermudah dan mempercepat para calon pembeli mobil menentukan mobil yang akan dibeli. Terdapat berbagai macam metode yang dapat diterapkan dalam membangun sebuah Sistem Pendukung Keputusan, diantaranya adalah metode Analytic Hierarchy Process (AHP) dan Fuzzy Associative Memory (FAM). Metode AHP adalah sebuah kerangka untuk mengambil keputusan dengan efektif dengan cara menyederhanakan dan mempercepat proses pengambilan keputusan dengan menyusun variabel yang ada ke dalam suatu susunan hierarki, memberi nilai numerik pada pertimbangan subjektif tentang pentingnya tiap variabel dan mensintesis berbagai pertimbangan untuk menetapkan variabel yang mana yang memiliki prioritas paling tinggi dan paling mempengaruhi hasil. Sedangkan metode FAM merupakan salah satu metode yang ada pada logika fuzzy yang dapat digunakan dalam penentuan pilihan terbaik dalam pengambilan keputusan. Dilakukan perbandingan hasil dari pengolahan menggunakan metode AHP dan FAM dengan menggunakan pengujian kualitas sistem dari segi aspek usability pada ISO 9126 untuk mengetahui metode manakah yang menghasilkan rekomendasi mobil paling sesuai dengan harapan calon pembeli mobil. Sistem yang dibuat ini dapat menjadi sebuah alat bantu untuk mempermudah dan mempercepat calon pembeli mobil dalam menentukan mobil yang sesuai dengan nilai kriteria dan kebutuhan calon pembeli mobil berdasarkan beberapa alternatif mobil yang menjadi pilihan calon pembeli mobil.

\section{B. Rumusan Masalah}

Dalam pembuatan proyek akhir ini terdapat beberapa perumusan masalah, antara lain:

1. Bagaimana membuat sebuah sistem pendukung keputusan untuk pembelian mobil.

2. Bagaimana mengimplementasikan penggunaan metode Analytic Hierarchy Process (AHP) dan Fuzzy Associative Memory (FAM) kedalam sebuah sistem pendukung keputusan untuk pembelian mobil.

C. Batasan Masalah

Adapun batasan masalah dalam pembuatan proyek akhir ini antara lain :

1. Sistem Pendukung Keputusan yang dibangun hanya sebagai alat bantu yang tidak bersifat mutlak, semua penilaian tergantung kepada pengambil keputusan sebagai pihak bertanggungjawab dalam pelaksanaan.

2. Kriteria yang digunakan pada sistem pendukung keputusan pembelian mobil ini didapatkan dari hasil pra riset yang telah dilakukan, yaitu harga, kapasitas silinder, kategori mobil, transmisi, kapasitas penumpang dan jenis mesin.

3. Sistem Pendukung Keputusan ini hanya digunakan untuk pembelian tiga merek mobil tervaforit berdasarkan hasil riset awal yang telah dilakukan, yaitu Toyota, Honda dan Daihatsu.

\section{LANDASAN TEORI}

\section{A. Tinjauan Pustaka}

Telah dilakukan sebuah penelitian tentang sistem pendukung keputusan untuk pemberian beasiswa di Universitas Panca Marga Probolinggo [3]. Sistem yang dibuat adalah aplikasi berbasis desktop dengan menggunakan java sebagai bahasa pemogramannya. Metode Simple Additive Weighting (SAW) diterapkan pada aplikasi tersebut. Metode tersebut digunakan untuk mengolah beberapa kriteria dalam pemberian beasiswa, dan kriteria yang digunakan adalah nilai IPK, penghasilan orang tua dan jumlah saudara kandung.

Penelitian lainnya adalah peneliatian tentang sistem pendukung keputusan untuk penerimaan mahasiswa baru di Politeknik Indramayu [4]. Aplikasi yang dibuat merupakan aplikasi berbasis Web dan SMS dengan menggunakan metode Fuzzy Associative Memory (FAM). Pada aplikasi ini kriteria yang olah adalah nilai ujian masuk, nilai ijazah, prestasi akademik, prestasi non akademik, usia dan juga penghasilan orang tua. Keluaran dari sistem ini adalah terima tidak diterimanya menjadi mahasiswa di Politeknik Indramayu.

Penelitian berikutnya adalah penelitian yang dibangun dengan menggunakan bahasa PHP dan database MySQL. Dengan mengunakan kriteria nilai harga beli, nilai harga jual kembali, bahan bakar, dan performa dibuat sebuah sistem pendukung keputusan pemilihan kendaraan roda empat menggunakan metode Analytic Hierarchy Process (AHP) [5].

Penelitian berikutnya adalah sistem pendukung keputusan dengan studi kasus pembelian smartphone [6]. Sistem dibangun menggunakan bahasa pemograman framework PHP dan dengan menggunakan metode Simple Additive Weight dan Fuzzy Associative Memory. Kriteria yang dipilih Marrina pada sistemnya adalah inti prosesor, clock prosesor, memori internal, Random Access Memory (RAM), kamera, baterai, dan harga.

Berdasarkan penelitian-penelitian yang telah dilakukan sebelumnya maka dibangun sebuah sistem pendukung keputusan dalam pembelian mobil dengan menggunakan metode Analytic Hierarchy Process (AHP) dan Fuzzy Associative Memory (FAM) dengan menggunakan bahasa pemograman PHP dan database MariaDB. Kriteria yang digunakan dalam sistem yang dibangun adalah harga, kapasitas silinder, kategori mobil, transmisi, kapasitas penumpang dan jenis mesin. 
Hasil yang akan diperoleh dari sistem ini berupa perankingan dan rekomendasi mobil yang sesuai dengan nilai kriteria dan kebutuhan calon pembeli mobil.

\section{B. Sistem Pendukung Keputusan}

Decision Support System (DSS) atau Sistem Pendukung Keputusan pertama kali dinyatakan oleh Michael S. Scott Morton pada tahun 1970 dengan istilah "Management Decision System" [7]. Pada dasarnya DSS dirancang untuk mendukung seluruh tahap pengambilan keputusan mulai dari mengidentifikasi masalah, memilih data yang relevan, menentukan pendekatan yang digunakan dalam proses pengambilan keputusan, sampai mengevaluasi pemilihan alternatif.

\section{Metode Analytical Hierarchy Process (AHP)}

Metode AHP merupakan sebuah pendekatan untuk pengambilan keputusan dengan melibatkan penataan kriteria yang ganda menjadi sebuah susunan hierarki, menilai tingkat kepentingan dari masing-masing kriteria, membandingkan alternatif untuk setiap kriteria dan melakukan ranking untuk keseluruhan alternatif [8].

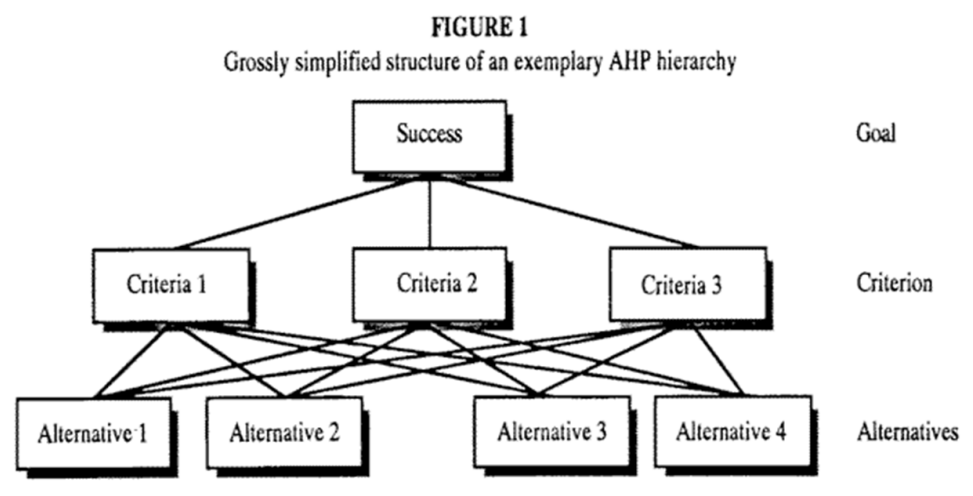

Gambar. 1 Hierarki pada Metode AHP

Tahapan-tahapan pengambilan keputusan dalam metode AHP pada dasarnya adalah sebagai berikut [9]:

1. Mendefenisikan masalah dan menentukan solusi yang diinginkan.

2. Membuat struktur hirarki yang diawali dengan tujuan umum, dilanjutkan dengan kriteria-kriteria dan alternatifalternatif pilihan yang ingin di rangking.

3. Membentuk matriks perbandingan berpasangan yang menggambarkan kontribusi relatif atau pengaruh setiap elemen terhadap masing-masing tujuan atau kriteria yang setingkat diatas. Perbandingan dilakukan berdasarkan pilihan atau judgement dari pembuat keputusan dengan menilai tingkat-tingkat kepentingan suatu elemen dibandingkan elemen lainnya.

4. Menormalkan data yaitu dengan membagi nilai dari setiap elemen di dalam matriks yang berpasangan dengan nilai total dari setiap kolom.

5. Menghitung nilai eigen vector dan menguji konsistensinya, jika tidak konsisten maka pengambilan data (preferensi) perlu diulangi. Nilai eigen vector yang dimaksud adalah nilai eigen vector maksimum yang diperoleh dengan menggunakan matlab maupun dengan manual.

6. Mengulangi langkah 3, 4, dan 5 untuk seluruh tingkat hirarki.

7. Menghitung eigen vector dari setiap matriks perbandingan berpasangan. Nilai eigen vector merupakan bobot setiap elemen. Langkah ini untuk mensintetis pilihan dalam penentuan prioritas elemen pada tingkat hirarki terendah sampai pencapaian tujuan.

8. Menguji konsistensi hirarki. Jika tidak memenuhi dengan $\mathrm{CR}<0,100$ maka penilaian harus diulangi kembali.

Nilai numerik yang dikenakan untuk seluruh perbandingan antara masing-masing kriteria diperoleh dari skala perbandingan 1 sampai 9 yang telah ditetapkan oleh Saaty, seperti pada tabel berikut ini [10]: 
TABEL 1 Skala Perbandingan Saaty

\begin{tabular}{|c|c|}
\hline $\begin{array}{c}\text { Tingkat } \\
\text { Kepentingan }\end{array}$ & Keterangan \\
\hline 1 & Kedua elemen mempunyai pengaruh yang sama. \\
\hline 3 & Elemen A sedikit lebih penting dari elemen B \\
\hline 5 & Elemen A lebih penting dari elemen B \\
\hline 7 & Elemen A jelas lebih penting dari elemen B \\
\hline 9 & Elemen A mutlak lebih penting dari elemen B \\
\hline $2,4,6,8$ & Nilai-nilai diantara dua pertimbangan yang berdekatan \\
\hline
\end{tabular}

Untuk setiap kriteria dan alternatif, perlu dilakukan perbandingan berpasangan (pairwise comparisons). Nilai-nilai perbandingan relatif kemudian diolah untuk menentukan peringkat alternatif dari seluruh alternatif. Baik kriteria kualitatif, maupun kriteria kuantitatif, dapat dibandingkan sesuai dengan penilaian yang telah ditentukan untuk menghasilkan bobot dan proritas. Bobot atau prioritas dihitung dengan manipulasi matriks atau melalui penyelesaian persamaan matematik. Pertimbangan-pertimbangan terhadap perbandingan berpasangan disintesis untuk memperoleh keseluruhan prioritas melalui tahapan-tahapan berikut:

a. Menjumlahkan kolom-kolom pada matriks perbandingan berpasangan sehingga membentuk matriks total.

b. Melakukan normalisasi matriks kemudian menjumlahkan setiap baris pada matriks tersebut dan hasilnya dibagi

dengan jumlah elemen, sehingga didapatkan nilai Eigen Vector (nilai prioritas).

AHP mengukur konsistensi dengan Consistency Ratio (CR). Mula-mula dengan menghitung Consistency Index (Cl) yang menggambarkan deviasi preferensi dari konsistensinya

$$
C I=\frac{\lambda \max -n}{n-1}
$$

dimana: $n=$ jumlah elemen yang akan dibandingkan $\lambda$ max = eigen value terbesar Nilai eigen value terbesar $=$ Matriks total pada matriks perbandingan berpasangan x Matriks Eigen Vector. Kemudian menghitung CR dengan rumus:

$$
C R=\frac{C I}{R I}
$$

Dimana, nilai RI (Random Index) dapat dilihat pada Tabel Nilai RI di bawah ini:

\begin{tabular}{|c|c|c|c|c|c|c|c|c|c|}
\hline $\begin{array}{c}\text { Ukuran } \\
\text { Matriks }\end{array}$ & 1 & 2 & 3 & 4 & 5 & 6 & 7 & 8 & 9 \\
\hline Nilai RI & 0 & 0 & 0.58 & 0.9 & 1.12 & 1.24 & 1.32 & 1.41 & 1.45 \\
\hline
\end{tabular}

Mencari nilai Consistency Ratio (CR) keseluruhan:

$$
\overline{C R}=\frac{\Sigma_{i} w_{i} C I_{i}}{\Sigma_{i} w_{i} R I_{i}}
$$

Dimana, i = jumlah kriteria dan alternatif $\mathrm{Cl}=$ Consistency Index $\mathrm{RI}=$ Random Index $\mathrm{w}$ (weight) = nilai Eigen Vector dan nilai untuk perkalian dengan $\mathrm{Cl}$ kriteria dan RI kriteria = 1 Sehingga persamaan 2 dapat dijabarkan menjadi persamaan 3 di bawah ini:

$$
\overline{C R}=\frac{(1 \times \text { CI Kriteria })+(\text { Matriks EV Kriteria } x \text { Matriks CI Alternatif })}{(1 \times \text { RI Kriteria })+(\text { Matriks EV Kriteria } x \text { Matriks RI Alternatif })}
$$

\section{Metode Fuzzy Associative Memory (FAM)}

Ada beberapa hal yang perlu diketahui dalam memahami sistem fuzzy, yaitu:[11]

1. Variabel fuzzy

Variabel fuzzy merupakan variabel yang hendak dibahas dalam suatu sistem fuzzy. Contoh: umur, temperatur, permintaan, dan lainnya.

2. Himpunan fuzzy

Himpunan fuzzy merupakan suatu grup yang mewakili suatu kondisi atau keadaan tertentu dalam suatu variabel fuzzy. Contoh: variabel umur terbagi menjadi 3 himpunan fuzzy yaitu muda, parobaya dan tua.

Himpunan fuzzy memiliki dua atribut, yaitu:

a. Linguistik, yaitu penamaan suatu grup yang mewakili suatu keadaan atau kondisi tertentu dengan menggunakan bahasa alami.

Numeris, yaitu suatu nilai (angka) yang menunjukkan ukuran dari suatu variabel. 
3. Semesta Pembicara

Semesta pembicaraan adalah suatu keseluruhan nilai yang diperbolehkan untuk dioperasikan dalam suatu variabel fuzzy. Nilai semesta pembicaraan berupa bilangan real positif maupun negative.

4. Domain

Domain himpunan fuzzy adalah keseluruhan nilai yang diijinkan dalam semesta pembicaraan dan boleh dioperasikan dalam suatu himpunan fuzzy. Nilai domain dapat berupa bilangan real positif maupun bilangan negatif.

Fuzzy Associative Memory (FAM) merupakan salah satu algoritma yang ada pada logika fuzzy. FAM adalah sebuah sistem yang memetakan himpunan fuzzy ke himpunan fuzzy yang lain [12].

Tahapan Fuzzy Assosiative Memory (FAM) adalah:

1. Mengkodekan input dan output ke dalam FAM matrix $\{(\mathrm{Ai}, \mathrm{Bi}) \mid 0<=\mathrm{i}<\mathrm{m}\}$ dimana $\mathrm{m}$ adalah jumlah data.

2. Menghitung auto associative fuzzy Hebbian FAM matriks dengan salah satu dari dua aturan pembelajaran, yaitu dengan correlation-minimum encoding atau dengan correlation product encoding.

3. Apabila nilai M sudah didapat, nilai B bisa dicari dengan melakukan relasi komposisi dari A dan M. Kita juga bisa mencari nilai A dengan melakukan relasi komposisi dari B dan M. Relasi komposisi bisa dilakukan dengan max-min composition atau dengan max-product composition.

4. Melakukan proses defuzzy dengan menggunakan aturan winner take all atau dengan menggunakan weighted average. Pada sistem yang dibangun ini menggunakan winner take all yang dimana alternatif dengan nilai terbesar akan menjadi rekomendasi terbaik.

\section{Perancangan}

\section{A. Arsitektur Sistem}

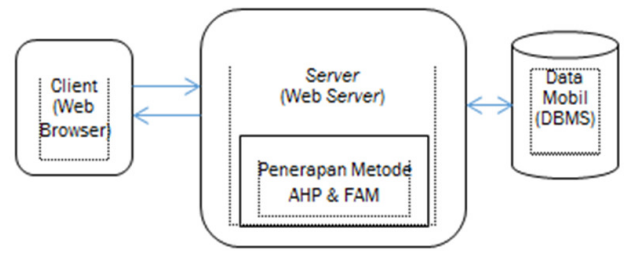

Gambar. 2 Arsitektur Sistem

Client dapat mengakses server melalui web browser. Pada web browser, calon pembeli mobil mengisi bobot kriteria untuk metode AHP dan nilai kriteria untuk metode FAM, kemudian bobot dan nilai kriteria tersebut disampaikan ke web server. Pada web server dilakukan pemrosesan dan perhitungan atas masukan calon pembeli mobil, dan data referensi berupa data spesifikasi/kriteria mobil diperoleh dari database. Perhitungan dilakukan menggunakan metode AHP dan FAM. Setelah dilakukan perhitungan maka server memberikan response kembali kepada client berupa perankingan dan rekomendasi mobil.

\section{B. Use Case Diagram}

Pada use case Diagram dijelaskan aktor-aktor yang berperan di dalam sistem serta apa saja yang dapat dilakukannya di dalam sistem. Use case Diagram pada sistem ini dijelaskan pada gambar 3.

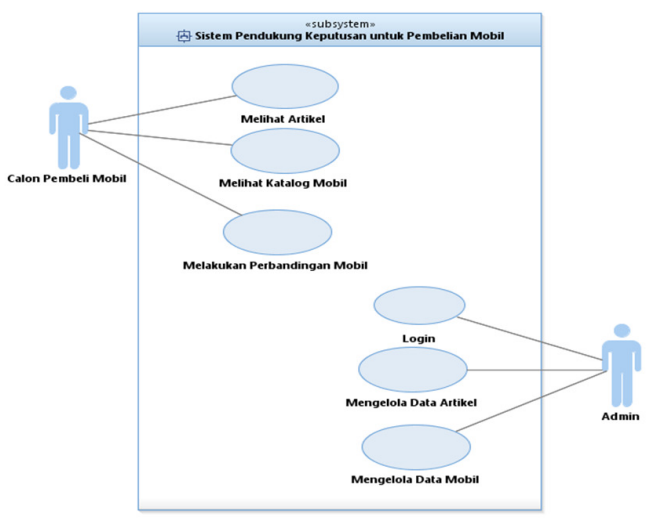

Gambar. 3 Use Case Diagram 
Sistem pendukung keputusan untuk pembelian mobil yang dibangun ini terdiri dari dua aktor, yaitu calon pembeli mobil dan admin. Calon pembeli mobil dapat melakukan tiga aksi pada sistem ini, yaitu melihat artikel, melihat katalog dan melakukan perbandingan terhadap alternative mobil yang menjadi pilihan. Sedangkan untuk aktor admin dapat melakukan login, mengelola data mobil serta dapat mengelola data artikel.

\section{Penentuan Kriteria}

Penentuan kriteria yang digunakan pada sistem pendukung keputusan untuk pembelian mobil ini dilakukan dengan proses penyebaran kuesioner. Kuesioner disebar kepada 100 orang responden dengan berbagai macam profesi. Kuesioner berisikan 9 buah penyataan mengenai kriteria yang dipertimbangkan saat ingin membeli sebuah mobil. Berdasarkan kuesioner yang telah disebar, kriteria mobil yang digunakan pada sistem pendukung keputusan untuk pembelian mobil ini adalah kategori mobil, kapasitas silinder, kapasitas penumpang, harga, transmisi dan jenis mesin.

\begin{tabular}{|c|c|c|c|}
\hline Kriteria & Data awal & $\begin{array}{c}\text { Data } \\
\text { konversi }\end{array}$ & $\begin{array}{c}\text { Fungsi } \\
\text { Keanggotaan }\end{array}$ \\
\hline \multirow{8}{*}{ Kategori Mobil } & Coupe & 1 & Coupe \\
\hline & Hybrid & 2 & Hybrid \\
\hline & Commercial & 3 & Commercial \\
\hline & Hatchback & 4 & Hatchback \\
\hline & Sedan & 5 & Sedan \\
\hline & Sport & 6 & Sport \\
\hline & SUV & 7 & SUV \\
\hline & MPV & 8 & MPV \\
\hline \multirow{5}{*}{ Harga } & $<=150.000 .000$ & 1 & Sangat Murah \\
\hline & $\begin{array}{l}>150.000 .000 \text { dan } \\
<=300.000 .000\end{array}$ & 2 & Murah \\
\hline & $\begin{array}{c}>300.000 .000 \text { dan } \\
<=450.000 .000\end{array}$ & 3 & Sedang \\
\hline & $\begin{array}{l}>450.000 .000 \text { dan } \\
<=600.000 .000\end{array}$ & 4 & Mahal \\
\hline & $>600.000 .000$ & 5 & Sangat Mahal \\
\hline \multirow{5}{*}{$\begin{array}{c}\text { Kapasitas } \\
\text { Penumpang(orang) }\end{array}$} & $<=2$ & 1 & Sangat Sedikit \\
\hline & $>2$ dan $<=4$ & 2 & Sedikit \\
\hline & $>4$ dan $<=6$ & 3 & Sedang \\
\hline & $>6$ dan $<=8$ & 4 & Banyak \\
\hline & $>8$ & 5 & Sangat Banyak \\
\hline \multirow{5}{*}{ Kapasitas Silinder(cc) } & $<=1000$ & 1 & Sangat Kecil \\
\hline & $>1000$ dan $<=1500$ & 2 & Kecil \\
\hline & $>1500$ dan $<=2000$ & 3 & Sedang \\
\hline & $>2000$ dan $<=2500$ & 4 & Besar \\
\hline & $>2500$ & 5 & Sangat Besar \\
\hline \multirow{2}{*}{ Transmisi } & Automatic & 1 & Automatic \\
\hline & Manual & 2 & Manual \\
\hline \multirow{2}{*}{ Jenis Mesin } & $\mathrm{DOHC}$ & 1 & $\mathrm{DOHC}$ \\
\hline & $\mathrm{SOHC}$ & 2 & $\mathrm{SOHC}$ \\
\hline
\end{tabular}

\section{Pengujian dan Analisa}

\section{A. Pengujian}

1. Hasil Perancangan Antarmuka

Gambar 4 merupakan antarmuka halaman utama untuk calon pembeli mobil. Terdapat 3 menu utama pada halaman utama ini.

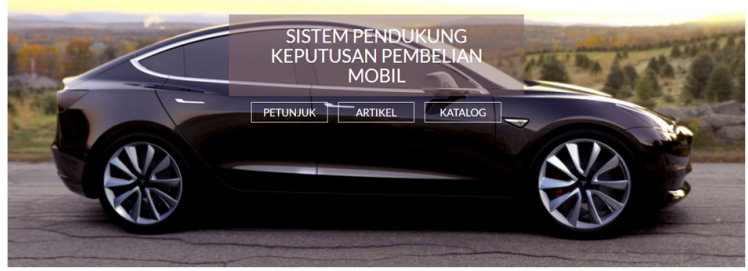

Gambar. 4 Antarmuka Halaman Utama 
Ketika memilih menu katalog pada halaman utama, calon pembeli mobil akan melihat halaman katalog seperti pada Gambar 5. Pada halaman ini terdapat daftar mobil yang dapat dipilih menjadi alternatif mobil yang akan dibandingkan.

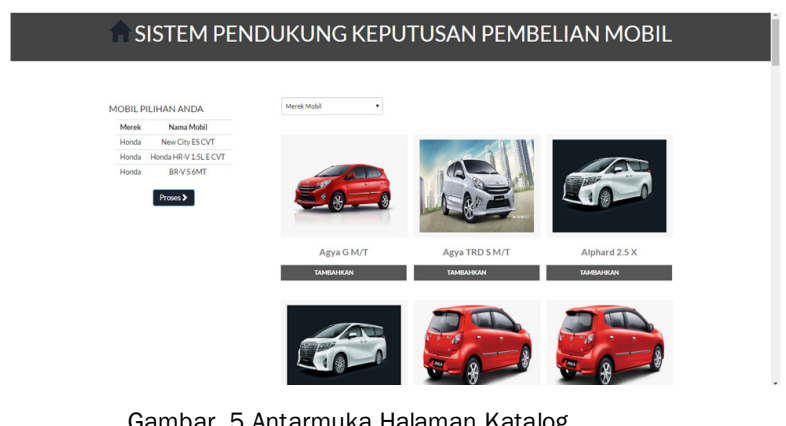

Setelah melakukan pemilihan alternatif mobil yang akan dibandingkan, calon pembeli mobil harus memberikan nilai bobot untuk masing-masing kriteria mobil. Calon pembeli mobil memasukkan bobot kriteria pada halaman penentuan bobot kriteria seperti pada Gambar 6.

A SISTEM PENDUKUNG KEPUTUSAN PEMBELIAN MOBIL

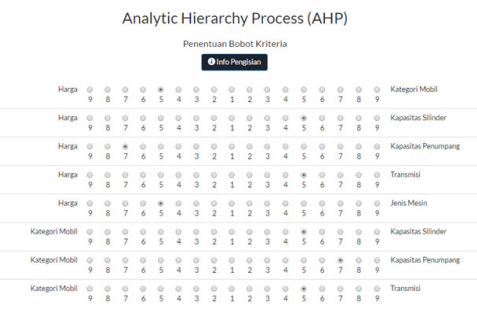

Gambar. 6 Antarmuka Halaman Penentuan Bobot Kriteria Metode AHP

Hasil pengolahan data menggunakan metode AHP berupa perangkingan mobil. Gambar 7 merupakan antarmuka halaman hasil perangkingan mobil hasil pengolahan metode AHP.

SISTEM PENDUKUNG KEPUTUSAN PEMBELIAN MOBIL

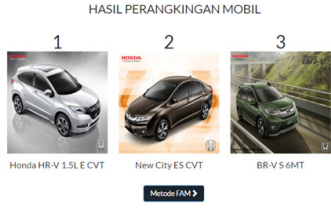

Gambar. 7 Antarmuka Halaman Hasil Perankingan Metode AHP

Metode FAM memerlukan nilai kriteria yang diinginkan para calon pembeli mobil untuk dapat melakukan pengolahan data. Calon pembeli mobil dapat memasukkan nilai kriteria yang diinginkannya pada halaman pengisian nilai kriteria. Gambar 8 merupakan antarmuka halaman pengisian nilai kriteria untuk metode FAM.

\section{SISTEM PENDUKUNG KEPUTUSAN PEMBELIAN MOBIL}

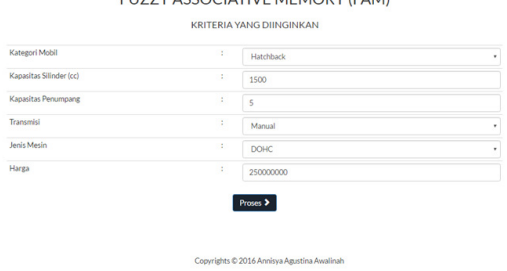


Gambar. 8 Antarmuka Halaman Pengisian Nilai Kriteria Metode FAM

Hasil pengolahan metode FAM berupa satu buah rekomendasi mobil. Gambar 9 menampilkan antarmuka halaman hasil rekomendasi mobil dari metode FAM.

\section{SISTEM PENDUKUNG KEPUTUSAN PEMBELIAN MOBIL}

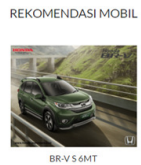

Gambar. 9 Antarmuka Halaman Rekomendasi Mobil Metode FAM

\section{Pengujian BlackBox}

Salah satu cara yang dapat dilakukan untuk melakukan pengujian blackbox adalah dengan menggunakan User Acceptance Tasting (UAT). Kuesioner UAT disebar pada 3 showroom mobil di Pekanbaru yaitu showroom Toyota Astra Sutomo Pekanbaru, showroom Honda Soekarno Hatta Pekanbaru, showroom Astra Daihatsu Pekanbaru. Pengujian dilakukan dengan membuat kelas uji yang didalamnya terdapat butir uji sistem untuk melihat bagaimana tingkat fungsionalitas sistem serta melihat apakah hasil yang dikeluarkan sistem sudah sesuai dengan yang diharapkan. Pengujian UAT ini juga dapat dijadikan bukti bahwa sistem yang dibangun sudah dapat diterima oleh pengguna atau perlu perbaikan. Berikut merupakan hasil pengujian blackbox UAT yang telah dilakukan.

TABEL 4 Hasil Rekapitulasi Kuesioner UAT

\begin{tabular}{|c|c|c|c|}
\hline No & Butir Uji & Ya & Tidak \\
\hline 1 & Menguji apakah sistem dapat melakuan login ke halaman admin & $100 \%$ & - \\
\hline 3 & Menguji apakah sistem dapat melakukan penambahan pada data mobil & $100 \%$ & - \\
\hline 5 & Menguji apakah sistem dapat melakukan hapus terhadpa data mobil & $100 \%$ & - \\
\hline 6 & Menguji apakah sistem dapat menampilkan daftar artikel & $100 \%$ & - \\
\hline 7 & Menguji apakah sistem dapat melakukan penambahan pada data artikel & $100 \%$ & - \\
\hline 9 & Menguji apakah sistem dapat melakukan hapus terhadap data artikel & $100 \%$ & - \\
\hline 10 & Menguji apakah sistem dapat memilih alternatif mobil & $100 \%$ & - \\
\hline 11 & $\begin{array}{l}\text { Menguji apakah sistem dapat memilih nilai bobot perbandingan antar kriteria untuk metode } \\
\text { AHP }\end{array}$ & $100 \%$ & - \\
\hline 12 & $\begin{array}{l}\text { Menguji apakah sistem dapat menampilkan hasil perankingan rekomendasi mobil dengan } \\
\text { metode AHP }\end{array}$ & $100 \%$ & - \\
\hline 17 & Menguji apakah sistem dapat menampilkan halaman artikel & $100 \%$ & - \\
\hline 18 & $\begin{array}{l}\text { Menguji apakah sistem dapat menampilkan halaman katalog alternatif mobil yang dapat } \\
\text { dipilih }\end{array}$ & $100 \%$ & - \\
\hline 19 & Menguji apakah sistem dapat menampilkan informasi tentang mobil yang dipilih & $100 \%$ & - \\
\hline 20 & $\begin{array}{l}\text { Menguji apakah sistem dapat menampilkan petunjuk pegisian nilai bobot perbandingan } \\
\text { antar kriteria }\end{array}$ & $100 \%$ & - \\
\hline
\end{tabular}

Berdasarkan hasil pengujian UAT yang dilakukan, didapatkan hasil bahwa sistem 100\% berhasil dibangun serta berjalan dengan baik, sesuai dengan yang diharapkan dan dapat diterima oleh pengguna.

\section{Pengujian Kuesioner terhadap Responden}

Pengujian dilakukan dengan melakukan penyebaran kuesioner terhadap 100 orang responden dari berbagai jenis profesi. Responden akan mengisi 2 buah kuesioner yaitu kuesioner untuk metode AHP dan kuesioner untuk metode FAM. Kuesioner berisikan butir pertanyaan seputar kualitas sistem dari aspek usability untuk masing-masing metode.

a. Kuesioner Metode AHP Hasil rekapitulasi kuesioner menggunakan metode FAM dapat dilihat pada Tabel 4. 
TABEL 5 Hasil Rekapitulasi Kuesioner Metode AHP

\begin{tabular}{|c|c|c|c|c|c|c|}
\hline \multirow{2}{*}{ No } & \multirow{2}{*}{ Butir Kriteria } & \multicolumn{5}{|c|}{ Skala } \\
\hline & & STS & TS & $\mathbf{R}$ & $\mathbf{S}$ & SS \\
\hline \multicolumn{7}{|c|}{ USEFULNESS } \\
\hline 1 & Sistem ini membantu saya menjadi lebih efektif & 0 & 3 & 9 & 43 & 45 \\
\hline 2 & Sistem ini bermanfaat & 1 & 4 & 8 & 37 & 50 \\
\hline 3 & Sistem ini memudahkan saya mencapai hal-hal yang saya inginkan & 1 & 3 & 11 & 47 & 38 \\
\hline 4 & Sistem ini sesuai dengan kebutuhan saya & 1 & 4 & 15 & 57 & 23 \\
\hline 5 & Sistem ini bekerja sesuai dengan apa yang saya harapkan & 1 & 5 & 16 & 53 & 25 \\
\hline \multicolumn{7}{|c|}{ EASE OF USE } \\
\hline 6 & Sistem ini mudah digunakan & 2 & 4 & 21 & 50 & 23 \\
\hline 7 & Sistem ini praktis untuk digunakan & 3 & 4 & 24 & 53 & 17 \\
\hline 8 & Sistem ini dapat disesuaikan dengan kebutuhan & 2 & 6 & 13 & 63 & 16 \\
\hline 9 & Tidak kesulitan menggunakan sistem ini & 2 & 10 & 15 & 57 & 16 \\
\hline 10 & Saya dapat menggunakan sistem tanpa instruksi tertulis & 3 & 7 & 19 & 57 & 14 \\
\hline 11 & Saya tidak melihat adanya ketidakkonsistenan selama saya menggunakannya & 2 & 4 & 10 & 57 & 27 \\
\hline \multicolumn{7}{|c|}{ EASE OF LEARNING } \\
\hline 12 & Sistem ini mudah saya pahami & 0 & 7 & 15 & 58 & 20 \\
\hline 13 & Saya belajar menggunakan sistem ini dengan cepat & 0 & 6 & 14 & 64 & 16 \\
\hline 14 & Saya mudah mengingat bagaimana cara menggunakan sistem ini & 0 & 8 & 6 & 54 & 32 \\
\hline 15 & Sistem ini mudah untuk dipelajari cara menggunakannya & 0 & 6 & 16 & 54 & 24 \\
\hline 16 & Saya menjadi mahir menggunakan sistem ini dalam waktu yang singkat & 0 & 7 & 5 & 52 & 36 \\
\hline \multicolumn{7}{|c|}{ SATISFACTION } \\
\hline 17 & Saya puas dengan sistem ini & 0 & 5 & 14 & 54 & 27 \\
\hline 18 & Saya akan merekomendasikan sistem ini kepada teman & 0 & 6 & 9 & 62 & 23 \\
\hline 19 & Sistem ini menyenangkan untuk digunakan & 0 & 9 & 17 & 57 & 17 \\
\hline 20 & Sistem ini bekerja seperti yang saya inginkan & 0 & 3 & 16 & 65 & 16 \\
\hline 21 & Sistem ini sangat bagus & 1 & 4 & 10 & 73 & 12 \\
\hline 22 & Sistem ini nyaman untuk digunakan & 0 & 5 & 13 & 67 & 15 \\
\hline
\end{tabular}

Berdasarkan rekapitulasi kuesioner untuk metode AHP pada tabel 4, maka dilakukan perhitungan untuk menghitung persentase keberhasilannya pada tabel 5.

TABEL 6 Perhitungan Rekapitulasi Kuesioner Metode AHP

\begin{tabular}{|c|c|c|c|c|c|c|c|c|c|c|}
\hline \multirow{2}{*}{ No } & \multicolumn{5}{|c|}{ Jumlah Nilai } & \multirow{2}{*}{ Total Nilai } & \multirow{2}{*}{ Skor Min } & \multirow{2}{*}{ Skor Max } & \multirow{2}{*}{ Persentase } & \multirow{2}{*}{ Kategori } \\
\cline { 2 - 5 } & STS & TS & R & S & SS & & & & \\
\hline 1 & 0 & 3 & 9 & 43 & 45 & 430 & 100 & 500 & $86 \%$ & Sangat Setuju \\
\hline 2 & 1 & 4 & 8 & 37 & 50 & 431 & 100 & 500 & $86,2 \%$ & Sangat Setuju \\
\hline 3 & 1 & 3 & 11 & 47 & 38 & 418 & 100 & 500 & $83,6 \%$ & Sangat Setuju \\
\hline 4 & 1 & 4 & 15 & 57 & 23 & 397 & 100 & 500 & $79,4 \%$ & Setuju \\
\hline 5 & 1 & 5 & 16 & 53 & 25 & 396 & 100 & 500 & $79,2 \%$ & Setuju \\
\hline 6 & 2 & 4 & 21 & 50 & 23 & 388 & 100 & 500 & $77,6 \%$ & Setuju \\
\hline 7 & 3 & 4 & 24 & 53 & 17 & 380 & 100 & 500 & $76 \%$ & Setuju \\
\hline 8 & 2 & 6 & 13 & 63 & 16 & 385 & 100 & 500 & $77 \%$ & Setuju \\
\hline 9 & 2 & 10 & 15 & 57 & 16 & 375 & 100 & 500 & $75 \%$ & Setuju \\
\hline 10 & 3 & 7 & 19 & 57 & 14 & 372 & 100 & 500 & $74,4 \%$ & Setuju \\
\hline 11 & 2 & 4 & 10 & 57 & 27 & 403 & 100 & 500 & $80,6 \%$ & Sangat Setuju \\
\hline 12 & 0 & 7 & 15 & 58 & 20 & 391 & 100 & 500 & $78,2 \%$ & Setuju \\
\hline 13 & 0 & 6 & 14 & 64 & 16 & 390 & 100 & 500 & $78 \%$ & Setuju \\
\hline 14 & 0 & 8 & 6 & 54 & 32 & 410 & 100 & 500 & $82 \%$ & Sangat Setuju \\
\hline 15 & 0 & 6 & 16 & 54 & 24 & 396 & 100 & 500 & $79,2 \%$ & Setuju \\
\hline 16 & 0 & 7 & 5 & 52 & 36 & 417 & 100 & 500 & $83,4 \%$ & Sangat Setuju \\
\hline 17 & 0 & 5 & 14 & 54 & 27 & 403 & 100 & 500 & $80,6 \%$ & Sangat Setuju \\
\hline 18 & 0 & 6 & 9 & 62 & 23 & 402 & 100 & 500 & $80,4 \%$ & Sangat Setuju \\
\hline 19 & 0 & 9 & 17 & 57 & 17 & 382 & 100 & 500 & $76,4 \%$ & Setuju \\
\hline 20 & 0 & 3 & 16 & 65 & 16 & 394 & 100 & 500 & $78,8 \%$ & Setuju \\
\hline 21 & 1 & 4 & 10 & 73 & 12 & 391 & 100 & 500 & $78,2 \%$ & Setuju \\
\hline 22 & 0 & 5 & 13 & 67 & 15 & 391 & 100 & 500 & $78,4 \%$ & Setuju \\
\hline
\end{tabular}

b. Kuesioner Metode FAM

Hasil rekapitulasi kuesioner menggunakan metode FAM dapat dilihat pada Tabel 7. 
TABEL 7 Rekapitulasi Kuesioner Metode FAM

\begin{tabular}{|c|c|c|c|c|c|c|}
\hline \multirow{2}{*}{ No } & \multirow{2}{*}{ Butir Kriteria } & \multicolumn{5}{|c|}{ Skala } \\
\hline & & STS & TS & $\mathbf{R}$ & $\mathrm{S}$ & SS \\
\hline \multicolumn{7}{|c|}{ USEFULNESS } \\
\hline 1 & Sistem ini membantu saya menjadi lebih efektif & 0 & 0 & 8 & 60 & 32 \\
\hline 2 & Sistem ini bermanfaat & 0 & 1 & 4 & 52 & 43 \\
\hline 3 & $\begin{array}{l}\text { Sistem ini memudahkan saya mencapai hal-hal } \\
\text { yang saya inginkan }\end{array}$ & 0 & 0 & 8 & 61 & 31 \\
\hline 4 & Sistem ini sesuai dengan kebutuhan saya & 0 & 0 & 16 & 58 & 26 \\
\hline 5 & $\begin{array}{l}\text { Sistem ini bekerja sesuai dengan apa yang } \\
\text { saya harapkan }\end{array}$ & 0 & 0 & 8 & 70 & 22 \\
\hline \multicolumn{7}{|c|}{ EASE OF USE } \\
\hline 6 & Sistem ini mudah digunakan & 0 & 0 & 6 & 62 & 32 \\
\hline 7 & Sistem ini praktis untuk digunakan & 0 & 1 & 17 & 42 & 40 \\
\hline 8 & $\begin{array}{l}\text { Sistem ini dapat disesuaikan dengan } \\
\text { kebutuhan }\end{array}$ & 0 & 0 & 17 & 47 & 36 \\
\hline 9 & Tidak kesulitan menggunakan sistem ini & 0 & 0 & 13 & 53 & 34 \\
\hline 10 & $\begin{array}{l}\text { Saya dapat menggunakan sistem tanpa } \\
\text { instruksi tertulis }\end{array}$ & 0 & 1 & 20 & 43 & 36 \\
\hline 11 & $\begin{array}{l}\text { Saya tidak melihat adanya ketidakkonsistenan } \\
\text { selama saya menggunakannya }\end{array}$ & 0 & 0 & 8 & 59 & 33 \\
\hline \multicolumn{7}{|c|}{ EASE OF LEARNING } \\
\hline 12 & Sistem ini mudah saya pahami & 0 & 0 & 10 & 51 & 39 \\
\hline 13 & $\begin{array}{l}\text { Saya belajar menggunakan sistem ini dengan } \\
\text { cepat }\end{array}$ & 0 & 1 & 14 & 39 & 46 \\
\hline 14 & $\begin{array}{l}\text { Saya mudah mengingat bagaimana cara } \\
\text { menggunakan sistem ini }\end{array}$ & 0 & 0 & 7 & 47 & 46 \\
\hline 15 & $\begin{array}{l}\text { Sistem ini mudah untuk dipelajari cara } \\
\text { menggunakannya }\end{array}$ & 0 & 0 & 11 & 46 & 43 \\
\hline 16 & $\begin{array}{l}\text { Saya menjadi mahir menggunakan sistem ini } \\
\text { dalam waktu yang singkat }\end{array}$ & 0 & 0 & 9 & 50 & 41 \\
\hline \multicolumn{7}{|c|}{ SATISFACTION } \\
\hline 17 & Saya puas dengan sistem ini & 0 & 0 & 9 & 50 & 41 \\
\hline 18 & $\begin{array}{l}\text { Saya akan merekomendasikan sistem ini } \\
\text { kepada teman }\end{array}$ & 0 & 0 & 13 & 60 & 27 \\
\hline 19 & Sistem ini menyenangkan untuk digunakan & 0 & 1 & 16 & 58 & 27 \\
\hline 20 & Sistem ini bekerja seperti yang saya inginkan & 0 & 1 & 13 & 52 & 34 \\
\hline 21 & Sistem ini sangat bagus & 0 & 0 & 11 & 64 & 25 \\
\hline 22 & Sistem ini nyaman untuk digunakan & 0 & 0 & 10 & 72 & 18 \\
\hline
\end{tabular}

Berdasarkan rekapitulasi kuesioner untuk metode AHP pada tabel 7, maka dilakukan perhitungan untuk menghitung persentase keberhasilannya pada tabel 8.

TABEL 8 Perhitungan Rekapitulasi Kuesioner Metode FAM

\begin{tabular}{|c|c|c|c|c|c|c|c|c|c|c|}
\hline \multirow{2}{*}{ No } & \multicolumn{5}{|c|}{ Jumlah Nilai } & \multirow{2}{*}{ Total Nilai } & \multirow{2}{*}{ Skor Min } & \multirow{2}{*}{ Skor Max } & \multirow{2}{*}{ Persentase } & \multirow{2}{*}{ Kategori } \\
\hline & STS & TS & $\mathrm{R}$ & $\mathrm{S}$ & SS & & & & & \\
\hline 1 & 0 & 0 & 8 & 60 & 32 & 424 & 100 & 500 & $84,8 \%$ & Sangat Setuju \\
\hline 2 & 0 & 1 & 4 & 52 & 43 & 437 & 100 & 500 & $87,4 \%$ & Sangat Setuju \\
\hline 3 & 0 & 0 & 8 & 61 & 31 & 423 & 100 & 500 & $84,6 \%$ & Sangat Setuju \\
\hline 4 & 0 & 0 & 16 & 58 & 26 & 410 & 100 & 500 & $82 \%$ & Sangat Setuju \\
\hline 5 & 0 & 0 & 8 & 70 & 22 & 414 & 100 & 500 & $82,8 \%$ & Sangat Setuju \\
\hline 6 & 0 & 0 & 6 & 62 & 32 & 426 & 100 & 500 & $83,2 \%$ & Sangat Setuju \\
\hline 7 & 0 & 1 & 17 & 42 & 40 & 421 & 100 & 500 & $84,2 \%$ & Sangat Setuju \\
\hline 8 & 0 & 0 & 17 & 47 & 36 & 419 & 100 & 500 & $83,8 \%$ & Sangat Setuju \\
\hline 9 & 0 & 0 & 13 & 53 & 34 & 421 & 100 & 500 & $84,2 \%$ & Sangat Setuju \\
\hline 10 & 0 & 1 & 20 & 43 & 36 & 414 & 100 & 500 & $82,8 \%$ & Sangat Setuju \\
\hline 11 & 0 & 0 & 8 & 59 & 33 & 425 & 100 & 500 & $85 \%$ & Sangat Setuju \\
\hline 12 & 0 & 0 & 10 & 51 & 39 & 429 & 100 & 500 & $85,5 \%$ & Sangat Setuju \\
\hline 13 & 0 & 1 & 14 & 39 & 46 & 430 & 100 & 500 & $86 \%$ & Sangat Setuju \\
\hline 14 & 0 & 0 & 7 & 47 & 46 & 439 & 100 & 500 & $87,8 \%$ & Sangat Setuju \\
\hline 15 & 0 & 0 & 11 & 46 & 43 & 432 & 100 & 500 & $86,4 \%$ & Sangat Setuju \\
\hline 16 & 0 & 0 & 9 & 50 & 41 & 432 & 100 & 500 & $86,4 \%$ & Sangat Setuju \\
\hline 17 & 0 & 0 & 9 & 50 & 41 & 432 & 100 & 500 & $86,4 \%$ & Sangat Setuju \\
\hline 18 & 0 & 0 & 13 & 60 & 27 & 414 & 100 & 500 & $82,8 \%$ & Sangat Setuju \\
\hline 19 & 0 & 1 & 16 & 58 & 27 & 417 & 100 & 500 & $83,4 \%$ & Sangat Setuju \\
\hline 20 & 0 & 1 & 13 & 52 & 34 & 419 & 100 & 500 & $83,8 \%$ & Sangat Setuju \\
\hline 21 & 0 & 0 & 11 & 64 & 25 & 414 & 100 & 500 & $82,8 \%$ & Sangat Setuju \\
\hline 22 & 0 & 0 & 10 & 72 & 18 & 408 & 100 & 500 & $81,6 \%$ & Sangat Setuju \\
\hline
\end{tabular}


Perbandingan persentase keberhasilan hasil rekapitulasi kuesioner dengan metode AHP dan FAM dapat dilihat pada Tabel 9.

TABEL 9 Perbandingan Persentase Keberhasilan Metode AHP dan FAM

\begin{tabular}{|c|c|c|c|c|}
\hline No & Butir Kriteria & $\begin{array}{l}\text { Persentase } \\
\text { AHP }\end{array}$ & $\begin{array}{l}\text { Persentase } \\
\text { FAM }\end{array}$ & $\begin{array}{c}\text { Persentase } \\
\text { Tertinggi }\end{array}$ \\
\hline \multicolumn{5}{|c|}{ USEFULNESS } \\
\hline 1 & Sistem ini membantu saya menjadi lebih efektif & $86 \%$ & $84,8 \%$ & AHP \\
\hline 2 & Sistem ini sangat bermanfaat & $86,2 \%$ & $87,4 \%$ & FAM \\
\hline 3 & $\begin{array}{l}\text { Sistem ini memudahkan saya mencapai hal yang saya } \\
\text { inginkan }\end{array}$ & $83,6 \%$ & $84,6 \%$ & FAM \\
\hline 4 & Sistem ini sesuai dengan kebutuhan saya & $79,4 \%$ & $82 \%$ & FAM \\
\hline 5 & $\begin{array}{l}\text { Sistem ini bekerja sesuai dengan apa yang saya } \\
\text { harapkan }\end{array}$ & $79,2 \%$ & $82,8 \%$ & FAM \\
\hline \multicolumn{5}{|c|}{ EASE OF USE } \\
\hline 6 & Sistem ini mudah untuk digunakan & $77,6 \%$ & $83,2 \%$ & FAM \\
\hline 7 & Sistem ini praktis untuk digunakan & $76 \%$ & $84,2 \%$ & FAM \\
\hline 8 & Sistem ini dapat disesuaikan dengan kebutuhan & $77 \%$ & $83,8 \%$ & FAM \\
\hline 9 & Saya tidak kesulitan menggunakan sistem ini & $75 \%$ & $84,2 \%$ & FAM \\
\hline 10 & Saya dapat menggunakan sistem tanpa instruksi tertulis & $74,4 \%$ & $82,8 \%$ & FAM \\
\hline 11 & $\begin{array}{l}\text { Saya tidak melihat adanya ketidak konsistenan selama } \\
\text { saya menggunakannya }\end{array}$ & $80,6 \%$ & $85 \%$ & FAM \\
\hline \multicolumn{5}{|c|}{ EASE OF LEARNING } \\
\hline 12 & Sistem ini mudah saya pahami & $78,2 \%$ & $85,5 \%$ & FAM \\
\hline 13 & Saya belajar menggunakan sistem ini dengan cepat & $78 \%$ & $86 \%$ & FAM \\
\hline 14 & $\begin{array}{l}\text { Saya mudah mengingat bagaimana cara menggunakan } \\
\text { sistem ini }\end{array}$ & $82 \%$ & $87,8 \%$ & FAM \\
\hline 15 & Sistem ini mudah untuk dipelajari cara penggunaannya & $79,2 \%$ & $86,4 \%$ & FAM \\
\hline 16 & $\begin{array}{l}\text { Saya menjadi mahir dalam menggunakan sistem ini } \\
\text { dalam waktu yang singkat }\end{array}$ & $83,4 \%$ & $86,4 \%$ & FAM \\
\hline \multicolumn{5}{|c|}{ SATISFACTION } \\
\hline 17 & Saya puas dengan sistem ini & $80,6 \%$ & $86,4 \%$ & FAM \\
\hline 18 & $\begin{array}{l}\text { Saya akan merekomendasikan sistem ini kepada teman } \\
\text { dan kerabat saya }\end{array}$ & $80,4 \%$ & $82,8 \%$ & FAM \\
\hline 19 & Sistem ini menyenangkan untuk digunakan & $76,4 \%$ & $83,4 \%$ & FAM \\
\hline 20 & Sistem ini bekerja seperti yang saya inginkan & $78,8 \%$ & $83,8 \%$ & FAM \\
\hline 21 & Sistem ini sangat bagus & $78,2 \%$ & $82,8 \%$ & FAM \\
\hline 22 & Sistem ini nyaman ketika digunakan & $78,4 \%$ & $81,6 \%$ & FAM \\
\hline
\end{tabular}

Berdasarkan Tabel 4.5, dapat dihitung untuk persentase keberhasilan dari masing-masing butir kriteria. Berikut hasil perhitungannya.

a. Usefulness

Metode $A H P=(1 \div 5) \times 100 \%=20 \%$

Metode FAM $=(4 \div 5) \times 100 \%=80 \%$

b. Ease of use

Metode $A H P=(0 \div 6) \times 100 \%=0 \%$

Metode FAM $=(6 \div 6) \times 100 \%=100 \%$

c. Ease of learning

Metode $A H P=(0 \div 5) \times 100 \%=0 \%$

Metode FAM $=(5 \div 5) \times 100 \%=100 \%$

d. Satisfaction

Metode $A H P=(0 \div 6) \times 100 \%=0 \%$

Metode FAM $=(6 \div 6) \times 100 \%=100 \%$ 
B. Analisa

1. Analisa Pengujian BlackBox

Berdasarkan hasil pengujian blackbox dengan melakukan penyebarkan kuesioner UAT terhadap 3 (tiga) showroom mobil di Pekanbaru didapatkan hasil bahwa sistem 100\% berhasil dibangun. Sistem berjalan sesuai dengan yang diharapkan dan dapat diterima oleh pengguna.

2. Analisa Pengujian terhadap Responden

Berdasarkan hasil rekapitulasi kuesioner terhadap 100 orang responden dapat di analisa bahwa dari segi usefulness calon pembeli mobil menyatakan bahwa metode FAM lebih berguna dibandingkan metode AHP. Kemudian dari segi ease of use, calon pembeli mobil menyatakan bahwa sistem dengan menggunakan metode FAM lebih mudah digunakan dibandingkan sistem dengan menggunakan metode AHP. Dari segi ease of learning , calon pembeli mobil menyatakan bahwa metode FAM lebih mudah dipelajari dibandingkan metode AHP. Dari segi satisfaction, responden lebih puas menggunakan sistem dengan metode FAM dibandingkan sistem dengan metode AHP.

\section{KESIMPULAN}

Adapun kesimpulan yang diperoleh dari hasil penelitian ini adalah:

1. Berdasarkan hasil pengujian blackbox dengan UAT, sistem pendukung keputusan untuk pembelian mobil $100 \%$ berhasil dibangun dan berjalan sesuai dengan yang diharapkan.

2. Berdasarkan hasil rekapitulasi kuesioner terhadap responden, calon pembeli mobil menyatakan bahwa sistem dengan menggunakan metode FAM lebih berguna, lebih mudah digunakan, lebih mudah dipelajari dan lebih menarik dibandingkan sistem dengan menggunakan metode AHP.

3. Berdasarkan hasil pengujian terhadap responden didapatkan hasil bahwa metode FAM lebih memberikan rekomendasi mobil yang sesuai dengan harapan calon pembeli mobil serta lebih mudah digunakan dibandingkan metode AHP. Sehingga untuk sebuah sistem pendukung keputusan untuk pembelian mobil metode FAM lebih tepat untuk diterapkan.

\section{REFERENSI}

[1] Gabungan Industri Kendaraan Bermotor. Diambil 2016 dari Domestic Auto Production By Category 2016 : http:// www.gaikindo.or.id/data-bykategori

[2] Aria, P. (2013). Tempo. Diambil Mei 2016 dari Tempo Otomotif : http://otomotif.tempo.co/read/news/2013/08/29/122508389/lima-alasanorang-indonesia-membeli-mobil

[3] Eprilianto, F.R., Sagirani, T., \& Amelia, T. (2012). Sistem Pendukung Keputusan Pemberian Beasiswa Menggunakan Metode Simple Additive Weighting di Universitas Panca Marga Probolinggo. Jurnal JSIKA, Vol.1, No.1.

[4] Bunga, M. S., \& Widyawan. (2015). Sistem Pendukung Keputusan Penerimaan Mahasiswa Baru dengan FAM (Studi Kasus : Politeknik Indramayu). Jurnal Nasional Teknik Elektro dan Teknik Informasi (JNTETI), Vol.4, No.4.

[5] Nugroho, A. C., \& Sukur, M. (2014). Perancangan Sistem Pendukung Keputusan Pemilihan Kendaraan Roda Empat Menggunakan Pemograman PHP dan MySQL. Dinamika Informatika, Vol.6, No.2.

[6] Marrina, Zul, M. I., \& Arifin, S. P. (2016). Sistem Pendukung Keputusan untuk Pembelian Smartphone Menggunakan Metode Simple Additive Weight dan Fuzzy Associative Memory. Jurnal Komputer Terapan, Vol.2, No.1.

[7] Budyanto, D. H., \& Soleman, A. (2013). Optimasi Sistem Pendukung Keputusan Penilaian Kinerja Pegawai Untuk Penentuan Pegawai Berprestasi Dengan Metode Profile Matching. Jurnal Teknologi Informasi, Vol.9, No.2: 2.

[8] Power, D.J. (2015). Analytical Hierarchy Process. Diambil dari Decision Support Systems Resources : http://www.dssresources.com/glossary/53.php

[9] Permadi, B. (1992). AHP. Jakarta: Pusat Antar Universitas - Studi Ekonomi Universitas Indonesia.

[10] Handoyo, T. (2013). Sistem Pendukung Keputusan Penerimaan Pegawai Dengan Metode AHP. Seminar Nasional Teknologi Informasi \& Komunikasi Terapan 2013 (p. 378). Semarang: STMIK Patria Magelang.

[11] Kusumadewi,Sri.Purnomo,Hari.(2004). Aplikasi Logika Fuzzy untuk Pendukung Keputusan.Yogyakarta: Graha Ilmu.

[12] Kosko, B. (1992). "Fuzzy System as Universal Approximator". IEEE Int. Conf. Fuzzy System 1153-1162. San Diego 